Pavel Hamet ${ }^{1}$ MD, PHD and Johanne Tremblay PhD

${ }^{1}$ Correspondance to Pavel Hamet, CRCHUM, 900 Saint-Denis street, Montreal, Quebec, Canada

At the onset the word "cancer "was invariably absent from the glossary of hypertension literature until 1974, when a warning against rauwolfia derivative, particularly reserpine, was issued for its potential of increasing the risk of breast cancer ${ }^{1}{ }^{3}$. In the following years, a series of articles were published concerning kidney cancer risk in users of diuretics ${ }^{4}$.

Noticeably, these were all retrospective observations. The first careful prospective analysis on that subject was performed by Dyer ${ }^{5}$ who demonstrated in a 14-year prospective follow-up, the association of several types of cancer with systolic and diastolic blood pressures, independently of therapy. Several prospective studies ${ }^{6}{ }^{9}$ subsequently demonstrated that hypertension per se, may be a culprit of cancer, as we have summarized previously ${ }^{10}$. Then, came out the calcium channel blockers accusation, a retrospective evidence collected from registries and published in important journals ${ }^{11,12}$, without any mention of the existing prospective evidence. In our mind, the major weakness of these analyses, was the neglect of indication bias: as usually a novel class of antihypertensive medication is used in the most severely affected subjects, and since hypertension levels appears to be an independent risk of cancer, those subjects are logically at higher risk, independently of their antihypertensive treatments. Notwithstanding the above, it seems that our field has a short memory: Repeatedly, the notion that calcium channel blockers increase the risk of cancer, particularly of breast and kidney cancers emerges in the literature ${ }^{13}$ and was disputed ${ }^{14}{ }^{15}$ and revived very recently ${ }^{16}$. It is important to note that when such risk factors as obesity and diabetes are being factored in, the evidence that hypertension is a risk of cancer, and more importantly that a decrease in blood pressure can attenuate that risk is rather convincing ${ }^{17}$.

The strongest level of evidence to the debate is contributed by systematic reviews and meta-analyses. Thus, Han et $\mathrm{al}^{18}$ presented in 2017, thirty studies that were separated according to their prospective or retrospective design. While the retrospective studies presented a relative risk (RR) of 1.29 ( $95 \% \mathrm{Cl}: 1.14-1.47)$, the prospective ones, that were more homogenous, and weighted for random effect, yielded a RR of 1.15 (95\% $\mathrm{Cl}: 1.08-1.22)$. The significant association was restricted to post-menopausal woman who had a RR of 1.19 (95\% Cl: $1.09-1.31)$. A more recent metaanalysis performed in 2019 by Seretis et al ${ }^{19}$ reported a positive and significant association between blood pressure and renal cancer specifically, in both sexes, with a RR of $1.5(95 \% \mathrm{Cl}: 1.31-1.75)$. A significant association was also reported in the prospective studies, for breast, stomach and colon cancers, even when multivariate adjustment was included.

We still do not have a clear picture of the mechanisms underlying the association between hypertension and cancer. The meta-analyses described above concluded to the need for Mendelian randomisation methodology to assess the potential causal role of hypertension in the incidence of cancer. We have initially proposed abnormalities of proliferation/apoptosis that are present in both cancer and hypertension, as a potentially shared mechanism ${ }^{10,20}$. Massive progress in Genome wide Association studies (GWAS) offers the opportunity to analyse shared genomic pathways and to develop polygenic risk prediction models.

As a first step we conducted a gene-centric look-up of genomic loci that were found to be associated to both, breast cancer and hypertension. Data for breast cancer were published in 2019 , and a polygenic risk score for prediction of breast cancer and breast cancer subtypes was developed using data from 79 studies conducted by the Breast Association Consortium. The best polygenic risk score included 313 SNPs21. The most comprehensive GWAS of blood pressure was reported by Mark Caulfield and Paul Elliott and their coworkers who identified 535 novel loci of blood pressure in 201822. The table below lists the 24 genes in common between the two studies as well as their main characteristics. Several of these genes were already known as being involved in the pathophysiological mechanisms of hypertension. Thus we previously demonstrated that proliferative and apoptotic anomalies throughout the life cycle of genetically hypertensive rats and mice include such genes as TGFB, FGF, p53 as well as genes regulating telomere homeostasis which led us to propose "Hypertension as a case of accelerated aging" 23 . We also demonstrated anomalies in the transcription of several members of the heat shock genes family in organs of genetically hypertensive rodents and even in circulating cells of humans and proposed hstf1 as the responsible gene ${ }^{24}$. We discovered a gene which is more expressed in several organs of genetically hypertensive rats and whose expression is negatively regulated by calcium levels. 
Overexpression of this gene, named Hypertension-related, calcium regulated gene (HCaRG) protects the kidney from ischemic injury ${ }^{25}$. In the context of this discussion, it is noteworthy that this gene, has been recently involved in renal carcinoma and may be a potential prognostic marker for this type of kidney cancer ${ }^{26,27}$.

Today technologies should help us to directly examine the genomic basis of the increased risk of cancer, particularly that of kidney cancer in hypertensive individuals. This information will be useful for the early identification of at-risk individuals and for prevention of this additional risk in subjects with hypertension.

\section{Key References}

5. Dyer AR, Stamler J, Berkson DM, Lindberg HA, Stevens E. High blood-pressure: a risk factor for cancer mortality? Lancet 1975;1:1051-6

13. Li Cl, Daling JR, Tang MT, Haugen KL, Porter PL, Malone KE. Use of antihypertensive medications and breast cancer risk among women aged 55 to 74 years. JAMA Intern Med 2013;173:1629-37.

18. Han H, Guo W, Shi W, et al. Hypertension and breast cancer risk: a systematic review and meta-analysis. Sci Rep 2017;7:44877.

19. Seretis A, Cividini S, Markozannes G, et al. Association between blood pressure and risk of cancer development: a systematic review and meta-analysis of observational studies. Sci Rep 2019;9:8565.

20. Hamet P. Cancer and hypertension: a potential for crosstalk? J Hypertens 1997;15:1573-7.

21. Mavaddat N, Michailidou K, Dennis J, et al. Polygenic Risk Scores for Prediction of Breast Cancer and Breast Cancer Subtypes. Am J Hum Genet 2019;104:21-34. 22. Evangelou E, Warren HR, Mosen-Ansorena D, et al. Publisher Correction: Genetic analysis of over 1 million people identifies 535 new loci associated with blood pressure traits. Nat Genet 2018;50:1755.

23. Hamet $P$, Thorin-Trescases N, Moreau $P$, et al. Workshop: excess growth and apoptosis: is hypertension a case of accelerated aging of cardiovascular cells? Hypertension 2001;37:760-6.

26. Matsuda H, Campion CG, Fujiwara K, et al. HCaRG/COMMD5 inhibits ErbB receptor-driven renal cell carcinoma. Oncotarget 2017;8:69559-76.

27.Campion CG, Zaoui K, Verissimo T, et al. COMMD5/HCaRG Hooks Endosomes on Cytoskeleton and Coordinates EGFR Trafficking. Cell Rep 2018;24:670-84 e7.

For full references click here

\begin{tabular}{|c|c|c|c|}
\hline Gene & Annotation & Location & Summary \\
\hline MDM4 & MDM4 regulator of $\mathrm{p} 53$ & $1 q 32.1$ & $\begin{array}{l}\text { Binds the p53 tumor suppressor protein and inhibit its activity and have been shown to be overexpressed } \\
\text { in a variety of human cancers. }\end{array}$ \\
\hline ATXN7 & Ataxin 7 & 3p14.1 & $\begin{array}{l}\text { The encoded protein is a component of the SPT3/TAF9/GCN5 acetyltransferase (STAGA) and TBP-free TAF- } \\
\text { containing (TFTC) chromatin remodeling complexes, and it thus plays a role in transcriptional regulation. }\end{array}$ \\
\hline TGFBR2 & $\begin{array}{l}\text { Transforming growth } \\
\text { factor beta receptor } 2\end{array}$ & $3 p 24.1$ & $\begin{array}{l}\text { Mutations in this gene have been associated with Marfan Syndrome, Loeys-Deitz Aortic Aneurysm } \\
\text { Syndrome, and the development of various types of tumors. }\end{array}$ \\
\hline LRBA & $\begin{array}{l}\text { LPS responsive beige-like } \\
\text { anchor protein }\end{array}$ & $4 q 31.3$ & Implicated in renal and colon cancer. \\
\hline AHRR & $\begin{array}{l}\text { Aryl-hydrocarbon } \\
\text { receptor repressor }\end{array}$ & $5 p 15.33$ & Involved in regulation of cell growth and differentiation. \\
\hline TERT & $\begin{array}{l}\text { Telomerase reverse } \\
\text { transcriptase }\end{array}$ & $5 p 15.33$ & $\begin{array}{l}\text { Telomerase expression plays a role in cellular senescence resulting in progressive shortening of telomeres. } \\
\text { Deregulation of telomerase expression in somatic cells may be involved in oncogenesis. }\end{array}$ \\
\hline HSPA4 & $\begin{array}{l}\text { Heat shock protein family } \\
\text { A (Hsp70) member } 4\end{array}$ & $5 q 31.1$ & $\begin{array}{l}\text { HSPA4 (Heat Shock Protein Family A (Hsp70) Member 4) is a protein coding gene involved in hypertension } \\
\text { and cancer. }\end{array}$ \\
\hline EBF1 & EBF transcription factor 1 & $5 q 33.3$ & $\begin{array}{l}\text { Gene ontology annotations related to this gene include DNA-binding transcription factor activity and } \mathrm{C} 2 \mathrm{H} 2 \\
\text { zinc finger domain binding. }\end{array}$ \\
\hline CDKAL1 & $\begin{array}{l}\text { CDK5 regulatory subunit } \\
\text { associated protein } 1 \text { like } 1\end{array}$ & $6 p 22.3$ & $\begin{array}{l}\text { The protein encoded by this gene is a member of the methylthiotransferase family. Genome-wide } \\
\text { association studies have linked single nucleotide polymorphisms in an intron of this gene with } \\
\text { susceptibility to type } 2 \text { diabetes. }\end{array}$ \\
\hline SMOC2 & $\begin{array}{l}\text { SPARC related modular } \\
\text { calcium binding } 2\end{array}$ & $6 q 27$ & $\begin{array}{l}\text { The encoded protein may serve as a target for controlling angiogenesis in tumor growth and myocardial } \\
\text { ischemia. }\end{array}$ \\
\hline LINC00536 & $\begin{array}{l}\text { Long intergenic non- } \\
\text { protein coding RNA } 536\end{array}$ & $8 q 23.3$ & Implicated in bladder and breast cancer and orthostatic intolerance. \\
\hline $\begin{array}{l}\text { FAM208B } \\
\text { (TASOR2) }\end{array}$ & $\begin{array}{l}\text { Transcription activation } \\
\text { suppressor family } \\
\text { member } 2\end{array}$ & $10 p 15.1$ & Transcription Activation Suppressor Family Member 2 is a Protein Coding gene. \\
\hline FGFR2 & $\begin{array}{l}\text { Fibroblast growth factor } \\
\text { receptor } 2\end{array}$ & $10 q 26.13$ & $\begin{array}{l}\text { The extracellular portion of the protein interacts with fibroblast growth factors, setting in motion a cascade } \\
\text { of downstream signals, ultimately influencing mitogenesis and differentiation. }\end{array}$ \\
\hline LSP1 & $\begin{array}{l}\text { Lymphocyte specific } \\
\text { protein } 1\end{array}$ & $11 \mathrm{p} 15.5$ & Its rs3817198 T>C polymorphism contributes to increased breast cancer risk. \\
\hline TBX3 & T-box 3 & $12 q 24.21$ & $\begin{array}{l}\text { T-box genes encode transcription factors involved in the regulation of developmental processes. Identified } \\
\text { for genome-wide significant associations with blood pressure in several ethnic groups. }\end{array}$ \\
\hline RPS27P25 & $\begin{array}{l}\text { Ribosomal protein } \mathrm{S} 27 \\
\text { pseudogene } 25\end{array}$ & $12 q 24.31$ & Pseudogene of unknown function. \\
\hline RIN3 & Ras and Rab interactor 3 & $14 q 32.12$ & $\begin{array}{l}\text { The protein encoded by this gene is a member of the RIN family of Ras interaction-interference proteins, } \\
\text { which are binding partners to the RAB5 small GTPases. }\end{array}$ \\
\hline RBFOX1 & $\begin{array}{l}\text { RNA binding fox-1 } \\
\text { homolog } 1\end{array}$ & $16 \mathrm{p} 13.3$ & Associated with blood pressure and cancer. \\
\hline CDYL2 & Chromodomain Y like 2 & $16 q 23.2$ & Gene ontology annotations related to this gene include methylated histone binding. \\
\hline ATAD5 & $\begin{array}{l}\text { ATPase family AAA } \\
\text { domain containing } 5\end{array}$ & $17 q 11.2$ & $\begin{array}{l}\text { Involved in a RAD9A-related damage checkpoint, a pathway that is important in determining whether DNA } \\
\text { damage is compatible with cell survival or whether it requires cell elimination by apoptosis. }\end{array}$ \\
\hline AQP4-AS1 & AQP4 antisense RNA 1 & $18 q 11.2$ & $\begin{array}{l}\text { AQP4-AS1 was identified as gene whose expression levels may contribute to the pleiotropy of complex } \\
\text { traits involved in cardiovascular health and blood pressure regulation. }\end{array}$ \\
\hline SETBP1 & SET binding protein 1 & $18 q 12.3$ & $\begin{array}{l}\text { The encoded protein has been shown to bind the SET nuclear oncogene which is involved in DNA } \\
\text { replication. }\end{array}$ \\
\hline ELL & $\begin{array}{l}\text { Elongation factor for RNA } \\
\text { polymerase II }\end{array}$ & $19 p 13.11$ & $\begin{array}{l}\text { ELL is elongation factor component of the super elongation complex (SEC), a complex required to increase } \\
\text { the catalytic rate of RNA polymerase II transcription by suppressing transient pausing by the polymerase } \\
\text { at multiple sites along the DNA. }\end{array}$ \\
\hline GIPR & $\begin{array}{l}\text { Gastric inhibitory } \\
\text { polypeptide receptor }\end{array}$ & $19 q 13.32$ & $\begin{array}{l}\text { This gene encodes a G-protein coupled receptor for gastric inhibitory polypeptide (GIP), which was } \\
\text { originally identified as an activity in gut extracts that inhibited gastric acid secretion and gastrin release, } \\
\text { but subsequently was demonstrated to stimulate insulin release in the presence of elevated glucose. }\end{array}$ \\
\hline
\end{tabular}

